\title{
Effects of Externally Applied IBA Doses on Rooting and Sapling Characteristics of Autumn Olive Berry Cuttings Taken at Different Periods
}

\author{
Hüseyin Çelik ${ }^{1, *}$, Damla Çil ${ }^{2}$ \\ ${ }^{1}$ Ondokuz Mayis University, Faculty of Agriculture, Department of Horticulture, Samsun, Turkey. \\ ${ }^{2}$ Hazelnut Research Institute, Giresun, Turkey.
}

How to cite this paper: Hüseyin Çelik, Damla Çil. (2021) Effects of Externally Applied IBA Doses on Rooting and Sapling Characteristics of Autumn Olive Berry Cuttings Taken at Different Periods. International Journal of the Science of Food and Agriculture, 5(1), 33-40. DOI: 10.26855/ijfsa.2021.03.006

Received: December 12, 2020

Accepted: January 8, 2021

Published: January 25, 2021

*Corresponding author: Hüseyin Çelik, Ondokuz Mayis University, Faculty of Agriculture, Department of Horticulture, Samsun, Turkey. Email: huscelik@omu.edu.tr

\begin{abstract}
Autumn olive berry is used as functional food due to the very high content of lycopene. It is a deciduous, perennial, temperate and/or subtropical berry fruits and has a woody bush. Autumn olive leaves, flowers, berries and bushes can be used for many purposes. It grows well at sunny areas and tolerates dry conditions with salty, clay, sandy and different $\mathrm{pH}$ soils. Autumn olive berry can be diverse with its seed eaten by birds. Cultivated autumn olive berry types generally propagate by cuttings. In the present study, hardwood, leafy green wood and semi hardwood cuttings taken from mother plants of autumn olive berry at March 15, May 15 and July 15. All type of cuttings applied with $0 \mathrm{ppm}$ (control), $500 \mathrm{ppm}$, 1,000 ppm and 2,000 ppm Indole-3-butryic acid (IBA) doses. Cuttings were planted in benches with perlite under misting at greenhouse conditions for rooting. The effect of cutting time and IBA application on the rooting rate (\%), root number, rooting degree (1-9), diameter and length of the saplings (cm) and salable sapling rate (\%) were determined. Pearson correlation among the features studied was also calculated. Cuttings taken at May with 1,000 or 2,000 ppm IBA and June with $500 \mathrm{ppm}$ gave the highest rooting rate (97.33\%). Root length is the best $(11.90 \mathrm{~cm})$ at May cuttings with $500 \mathrm{ppm}$ IBA. May cuttings with 1,000 ppm IBA gave the best salable sapling rate (89.33\%). The best cutting time was 15 May and the best IBA dose is the 1,000 ppm for most characteristics, investigated.
\end{abstract}

\section{Keywords}

Autumn olive berry, Elaeagnus umbellata, cutting time, IBA, rooting

\section{Introduction}

Autumn olive berry (Elaeagnus umbellata Thunb.) is a perennial and deciduous shrub. Although there are 40 species in the Elaeagnaceae family, the most important one has been revealed by the researchers that it is Autumn olive berry. It has a natural spread between 1,200-2,100 m altitudes in Pakistan, China, India, Korea and Japan, pH demand is between 4-8, it can easily grow in inefficient and abandoned areas and its adaptation to dry conditions is very good [1, 2, 3]. It prefers sunny areas and it is capable of growing in salty, clayey and sandy soils with different $\mathrm{pH}$ values. It can tolerate drought and extreme winter colds, but it is a plant that cannot grow in shade areas and is difficult to grow in rainy-wet areas. It is recommended for the beach areas and for the places where there is salt spray. It can easily grow in barren, unproductive meadow and abandoned areas. It spreads spontaneously with seeds in a natural environment. It can adapt to many different climatic and soil conditions and it produces the nutrient itself. It grows well in deep, sandy, clayey and fine and well-drained soils. It is a plant suitable for open areas in the forests, garden edges, roadsides, mea- 
dow-grassy areas and barrens. It grows very quickly and covers the area where it is planted in a short time. It is a functional berry food and has a big potential as cash [4]. Autumn olive berry is generally reproduced with seeds. However, after the cultivation of the fruit started, varieties such as "Cardinal”, "Ellagold”, "Chalies Golden”, "Elsberry”, "Redwing" and "Brilliant Rose" were selected and reproduced with cutting. In order to increase germination in the seeds, it is folded in the cold, the seedlings are planted in the field in spring or the seeds are sown directly in the land in autumn [3, $5,6,7,8,9,10,11,12]$.

It is a species that can be used pharmacologically as well as it is useful for ecology, soil and wildlife. Its flowers are important for bees and butterflies and contribute to honey production, and are used as a blood stopper, perfume industry, cough treatment and heart diseases [3]. It is a good ornamental plant for landscaping with its leaf color, shrub form and easy to prune. In forestry activities, landscaping, wildlife, soil protection, degraded, barren, empty areas, combating erosion, forming a fence, turning around agricultural areas, forming trenches or windbreak, protecting slope and median on roads, afforestation. It is widely used in gardens. It is an excellent plant for agriculturalists and environmental designers as it can easily grow in extraordinary yard and heavy conditions, heavy metal areas and abandoned barren, sloping, stony-rocky areas [3, 4, 13, 14]. It lives in common with Frankia bacteria in roots and fixes the free nitrogen of the air to the soil $[8,9,10,13,14]$. There are no diseases and/or pest for harm. Its dark red fruits are slightly acrid and tomato-like taste, ripening in October-November. Its fruits can be consumed fresh as well as used in making fruit pulp, fruit juice, jam, jelly and sauce. It is a good food source for wildlife animals and birds. It is recommended as an intermediate plant in black walnut growing areas. The Autumn olive berry, which was taken to America in the 1800s for erosion control, is an exotic fruit and used as a traditional food source in the far east $[1,2,3,7,15]$.

Vegetative propagation enables to get superior new plants by protecting their genetic base [16]. Cutting propagation is one of the widely used vegetative propagation methods, is simple, fast and cheap technique. This propagation technic enables to get many numbers of plants to be produced from fewer individuals located in a small area. Also, it does not require special techniques such as in grafting and micro vegetative propagation methods. There is no inconsistency problem with rootstock in cutting propagation method as in the propagation with grafting [17]. Plant growth regulators have also great importance during the cutting propagation. It is generally accepted that auxins play a central role in the rooting formation [17].

In the target of the present study, it was tried to determine the effects of exogenous IBA doses and cutting taking time on propagation of Elaeagnus umbellate by cuttings. Rooting, root length, root number, rooting degree, sapling diameter and length and salable sapling rate were determined. And Pearson's correlation between the investigated characteristics was also determined.

\section{Methods}

\subsection{Design and Sample}

In the study, cutting propagation method used to propagate the Autumn olive berry variety, selected from eastern part of Black Sea Region at the year of 2010 and their plants planted in the Research Area of the Agricultural Faculty (41 $21^{\circ} 52 \mathrm{~N}$ and $36^{\circ} 11 ' 29 \mathrm{E}, 195 \mathrm{~m}$ above sea level) at the years of 2015-2016. Cuttings (hardwood from one-year-old wood, leafy green wood and leafy semi hardwood cuttings from the current year growth) to be used as study material were obtained from the eight-years-old mother-stock plants (Figure 1). Cutting took at the date of March 15, May 15 and June 15. March 15 cuttings had no leaf but others have just one leaf at the top. All cuttings disinfected according to Çelik [16], and cut into $25 \mathrm{~cm}$ long before auxin application. All cuttings after disinfection treated with five different IBA (Indole-3-Butyric Acid) doses (0 ppm as control, 500 ppm, 1,000 ppm and 2,000 ppm) as quick deep. Then the propagation materials planted in the propagation benches with $30 \mathrm{~cm}$ deep perlite has high water retention capacity and ventilation porosity (Figure 2). All benches had bottom heating with $22^{\circ} \mathrm{C}$ constant temperature gained with electrical cables and thermostat control unit [18], over misting system for 75\% humidity, $40 \%$ green-shade-net and constructed in greenhouse condition with $25^{\circ} \mathrm{C}$ ambient temperature. Greenhouse air temperature controlled via misting and top-air ventilation. The study was set up at three replications, according to the "randomized complete block design" under split plots. A total of 900 cuttings were planted to rooting media including 1 species x 4 IBA doses x 3 cutting take time $\mathrm{x} 1$ media $\times 3$ replications x 25 cuttings for each replication. The irrigation was made after the cuttings were transferred to the rooting media. Thus, it was ensured that the cuttings were fully seated in the rooting media. In the study, percentage of rooting, root length and number, rooting degree (1-9), sapling diameter and length and salable sapling rate were determined. The rooting percentage was expressed as a percentage of the total cutting by determining the number of cuttings forming the root. Root length was the length of roots formed in cuttings. And root number decided whether the cuttings should be removed from the rooting medium according to the rooting condition. Rooting degree as expressed 1-9 scale calculated by the root formation of the cuttings as, 1-no root, 3-weak roots, 5-medium roots, 7-strong roots and 9-very strong root formation put forward by analogy with the report of Çelik [16] and Çelik et al. [19]. ArcSinN transformation was applied to the percentage values, while statistical analyzes were performed with the SPSS-23 statis- 
tical program, and the real difference between the cutting taking time, IBA doses and their interactions was evaluated by Duncan Multiple Range Test. On the other hand, "Pearson Correlation Values” also calculated between all the investigated characteristics.
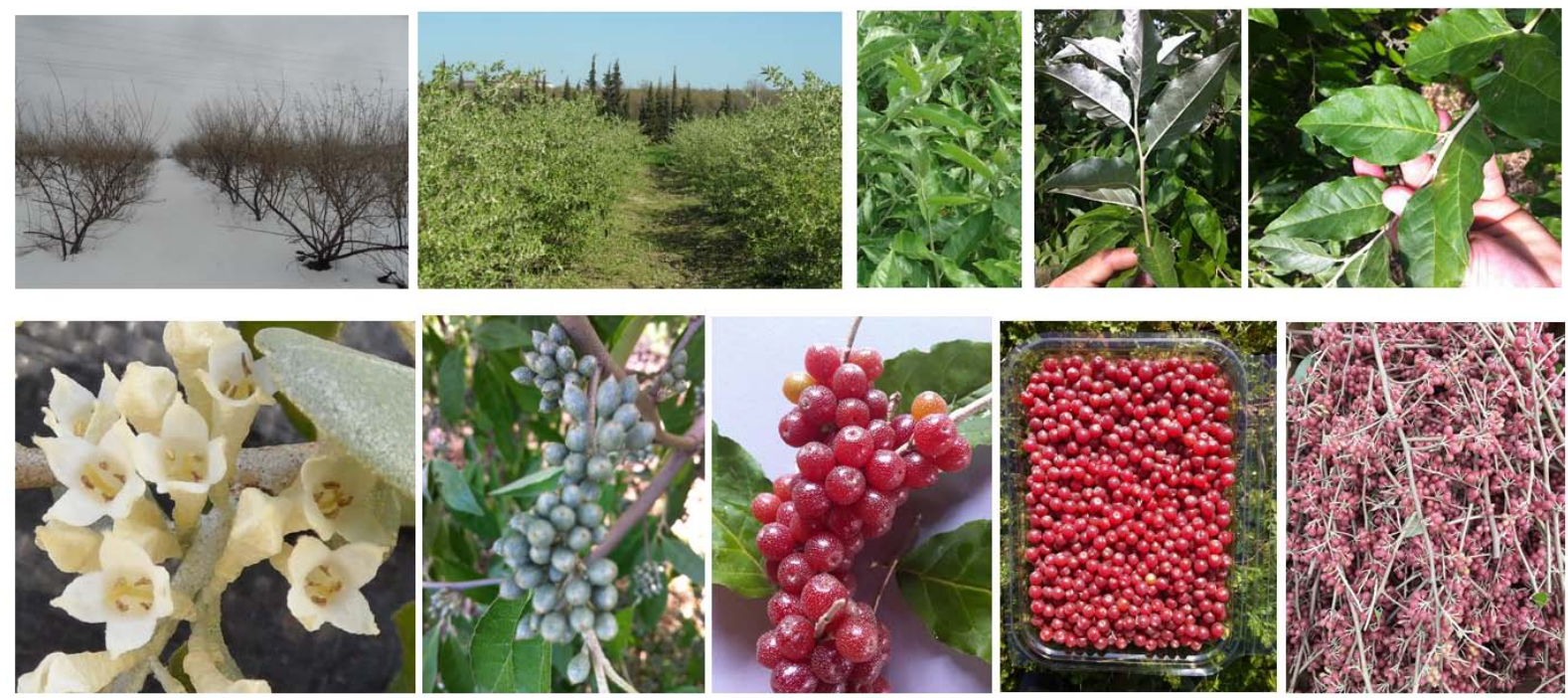

Figure 1. Autumn olive berry orchard (dormant period and active growing season), bushes, leaves, flowers, un-mature and mature fruits and hand harvested (in clam shell) berries and fruity shoots for sale (Photos are original, by $\mathrm{H}$. Çelik).
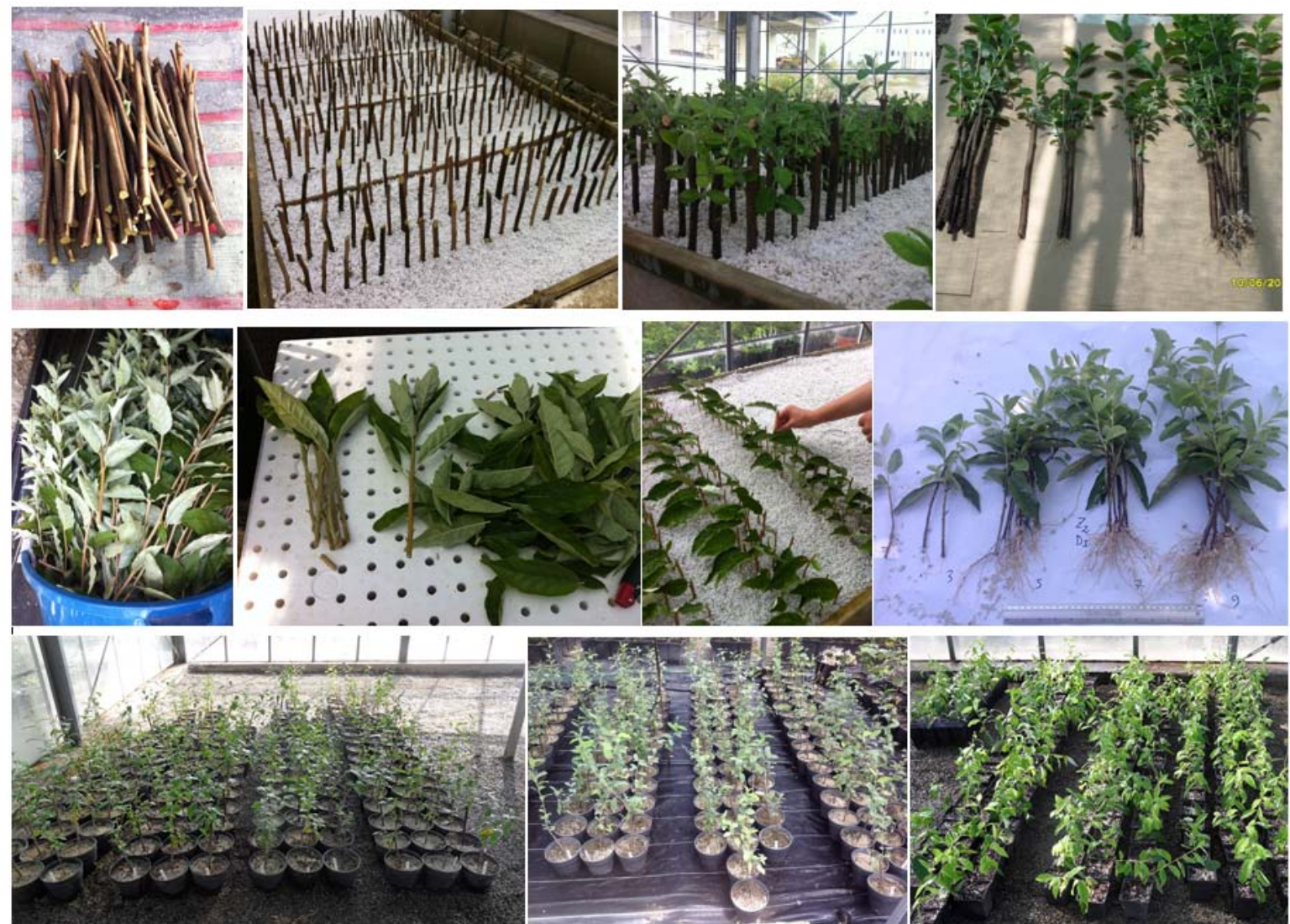

Figure 2. Autumn olive berry hard-wood cuttings taken in winter, their preparation, planting in benches with perlite, rooting and rooting data observation (top, at the first line from left to right). Green bushes taken for current season growth, leafy green and semi hard-wood cuttings preparation, planting and evaluation (middle, left to right). And saplings gained from vegetative propagated both woody and leafy cuttings planted in pots for growing in and out of the greenhouse under shade net (Photos are original, by $\mathrm{H}$. Çelik). 


\section{Results and Discussion}

Autumn olive berry has begun to become widespread as a functional food source due to the high lycopene contains. The new orchard establishment increased recently with selection breed new cultivars around the world. As a new and functional berry fruits, autumn olive berry vegetative propagated and the effect of exogenous IBA application and cutting collection time on rooting and sapling growth and yield were evaluated with the present study. For this purpose, woody cuttings (March 15), leafy-green cuttings (May 15) and semi hard-wood leafy cuttings (July 15) collected from stock mother plant and treated with different IBA doses (0, 500, 1,000 and 2,000 ppm). The best results in terms of rooting rate in the experiment were obtained in July cuttings treated with $500 \mathrm{ppm}$ IBA (97.33\%). Therefore, it was determined that the interaction between cutting receiving time and externally applied IBA dose was the most important and the highest (Table 1). It was revealed that the rooting rate of leafy-green-wood cutting taken in May in terms of the time of taking the cutting gave the best rooting result with $94.33 \%$, while the $500 \mathrm{ppm}$ dose from the IBA applications gave the highest rooting rate with $84.89 \%$. The rooting rate of the cuttings taken in the rest period in March (57.33\%) and the control IBA applied cuttings (77.78\%) remained at the lowest values. Accordingly, in order to get the best results in terms of rooting rate, application of $500 \mathrm{ppm}$ IBA to leafy green cuttings taken in July will be sufficient (Table 1). As a matter of fact, Baktir [20] and Porghorban et al. [21] is also indicated that the rooting rate could be differed to cutting take time. According to Bayraktar et al. [22] who propagate Autumn olive berry with dormant cuttings, the highest rooting percentage was $70.00 \%$ in 5,000 ppm IBA treatment, and the lowest one obtained from control group (33.33\%). Our findings with dormant cuttings were lower but leafy green cuttings with only 500 ppm IBA gave higher rooting rate than their findings.

Table 1. Rooting and root growth of Autumn olive berry cuttings taken at different time and treated with different IBA doses

\begin{tabular}{|c|c|c|c|c|c|}
\hline Cutting time & IBA (ppm) & Rooting (\%) & Root length (cm) & Root number & Rooting degree (1-9)* \\
\hline \multirow[t]{4}{*}{ March } & 0 & $48.00 \mathrm{c}$ & 3.98 & 12.06 & 3.88 \\
\hline & 500 & $65.33 \mathrm{c}$ & 3.08 & 10.47 & 4.15 \\
\hline & 1,000 & $64.00 \mathrm{c}$ & 3.34 & 10.35 & 4.39 \\
\hline & 2,000 & $52.00 \mathrm{c}$ & 3.31 & 10.43 & 4.20 \\
\hline \multirow[t]{4}{*}{ May } & 0 & $90.67 \mathrm{~b}$ & 10.00 & 5.01 & 4.55 \\
\hline & 500 & $92.00 \mathrm{ab}$ & 11.90 & 5.10 & 5.35 \\
\hline & 1,000 & $97.33 \mathrm{ab}$ & 8.99 & 7.53 & 5.24 \\
\hline & 2,000 & $97.33 \mathrm{ab}$ & 10.49 & 5.23 & 5.48 \\
\hline \multirow[t]{4}{*}{ July } & 0 & $94.67 \mathrm{ab}$ & 11.15 & 6.01 & 5.69 \\
\hline & 500 & $97.33 \mathrm{a}$ & 10.72 & 5.98 & 5.27 \\
\hline & 1,000 & $90.67 \mathrm{~b}$ & 9.06 & 7.33 & 6.00 \\
\hline & 2,000 & 89.33 b & 13.35 & 6.97 & 5.61 \\
\hline \multicolumn{2}{|c|}{ Significancy } & $\mathrm{P}<0.05$ & N.S** & N.S & N.S \\
\hline
\end{tabular}

*Rooting degree: 1-no root, 3-weak roots, 5-medium roots, 7-strong root and 9-very strong root formation. **N.S: Non significant

Autumn olive berry mostly used as ornamentals and/or road side afforestation and commonly propagated with seed by mankind and dispersal seeds by birds. Therefore, little work has been done on its vegetative propagation. For example, Bounous et al. [23] found that the cutting collecting time or IBA doses was ineffective upon rooting of the dormant cuttings of Autumn olive berry. Bayraktar et al. [22] achieved 70.00\% rooting success from 5,000 ppm IBA dose applied to winter dormant cuttings. While the findings we obtained in our study were in contradiction with the findings of Bounous et al. [23], but Bayraktar et al. [22] findings were higher than our results when use dormant cuttings. In particular, we obtained much higher rooting degree than Bayraktar et al. [22] by using lowest IBA doses with leafy green cuttings. Because the use of hormones is not enough for the cuttings to form roots, and many factors such as the time of taking the cutting, the development status of the mother plant, the texture property of the plant, ambient and rooting media temperature, humidity, light level and the rooting environment are taken into consideration [20, 24, 25]. On the other hand, the time of taking the cuttings and the location of the cutting on the shoots can significantly affect the development of the sapling with the root formation [26]. This situation was reported by Hartmann et al. [17] and Ruter [26] and Beyl et al. [24] was also determined that the rate of rooting may vary depending on fruit species, even varieties and 
the auxin dose used. On the other hand, Preet and Vishal [27] stated that the rooting percentage of kiwi semi-woody cuttings is the best obtained from the mid-July ant threated with 5,000 ppm IBA. Meanwhile, Zenginbal and Özcan [28] stated that 4,000-6,000 ppm IBA application can be achieved by $83.00 \%$ rooting in winter kiwifruit cuttings taken in January or February, and Zenginbal and Özcan [29] reported that the same applications in the July-August kiwi fruit cuttings showed $86.00 \%$ rooting. Kim et al. [30] stated that the time of taking cutting in acacia plant and the 1,000 ppm IBA dose of auxin had a positive effect on the rooting rate and their findings support to our study results. Similar results were also revealed in the oleander plant by Şeker et al. [31] in arbutus, Pivetta et al. [32]. Çelik et al. [19] in cherry laurels, Çelik [16] in blueberries and Kim et al. [30] in acacia can also state that rooting change according to the cutting taking time. It is also stated that the Autumn olive berry can easily be rooted under semi-woody cuttings under mist watering, but it is mandatory to apply 8,000 ppm IBA in powder form [24]. However, we proved that Autumn olive berry could be propagated successfully by lower doses of IBA. On the other hand, the success of cutting propagation depends on rooting and root quality. Rooting and root quality also depends on medium type, woody or herbaceous cuttings type [25], temperature for both ambient air and rooting medium where the bottom of the cutting is located [21].

The final product is the salable sapling of vegetative propagated plants. The number, length and diameter of the shoots in the saplings, the length of the saplings, the level of root development, the length and the number of roots are the main characteristics of salable and quality determinants [17, 28]. It was found that the root length of dormant cuttings in the study was low, and higher in semi hardwood cuttings taken during active growing season with leaf, regardless of the application of IBA. As a matter of fact, when 2,000 ppm IBA was applied to leafy semi hardwood leafy cuttings taken in July, the root length was highest with $13.35 \mathrm{~cm}$. On the contrary, it was determined that the number of roots was higher in woody cuttings (March cuttings and 12.06 pieces) taken during the dormant period (Table 1). On the other hand, it was determined that the root length $(11.07 \mathrm{~cm})$ in the Autumn olive berry cuttings taken in July was higher than the winter cuttings $(3.43 \mathrm{~cm})$ taken in March. In terms of IBA, root length $(9.05 \mathrm{~cm})$ has reached the highest value in cuttings with 2,000 ppm (Figures 3 and 4). This may be related to earlier rooting and feeding in leafy May and July cuttings. Similar results have been revealed by Çelik [16] in the studies on the vegetative reproduction of blueberries. On the other hand, Ruter [26] supports the results obtained from this study, stating that the growth and development of cuttings can be affected by the time of taking the cutting and even where the cuttings are located on the shoot. In the trial, as the dose of auxin (IBA) increases, the length of the root generally increases, while the number of roots varies (Tables 3 and 4). In terms of rooting degree, the time of taking the cutting and IBA dose interaction, leafy July cuttings with 1,000 ppm IBA had a strong root formation (6.0) and they have the highest rooting degree. As the IBA dose increases, the degree of rooting is positively affected and the degree of rooting in leafy and semi hardwood cuttings revealed to be higher. On the other hand, the rooting degree of hardwood cuttings taken in March and without IBA dosing was found to be the lowest with 3.88. According to the cutting take time, it was also determined that the rooting degree (5.64) of leafy cuttings taken in July was the highest. To the IBA doses, 1,000 ppm application gave the highest rooting degree (5.21). On the other hand, Autumn olive berry cuttings without IBA application had the lowest rooting degree as 4.71 (Figures 3 and 4).

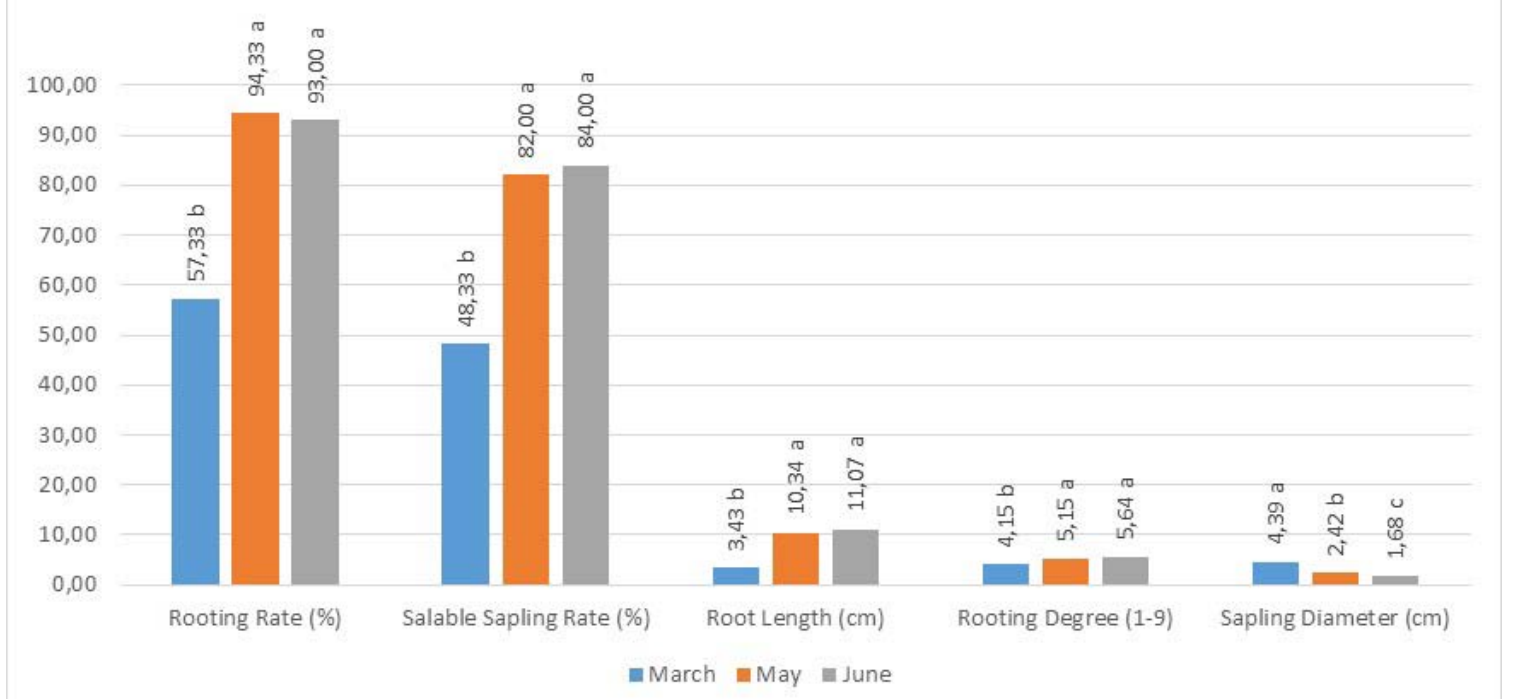

Figure 3. Rooting and salable sapling rate, root length and rooting degree and sapling diameter according to cutting collecting time. 


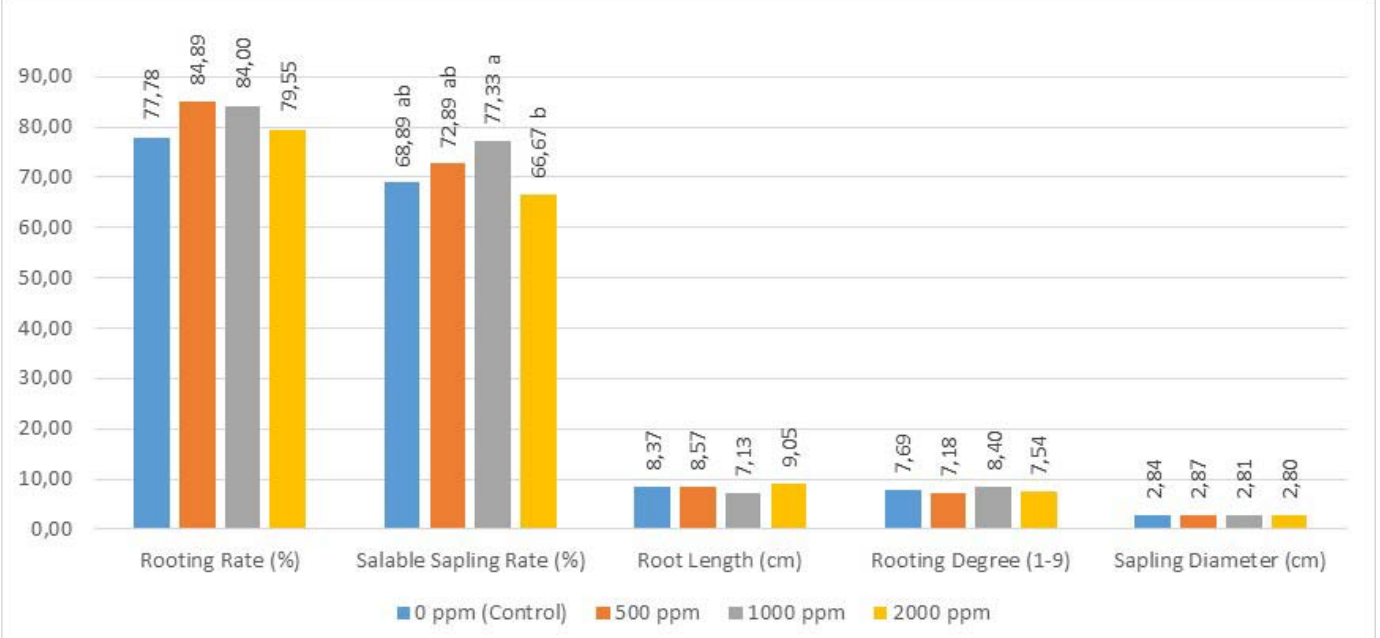

Figure 4. Rooting and salable sapling rate, root length and rooting degree and sapling diameter according to IBA doses.

It was determined that the diameter of the saplings in hardwood cuttings, which were taken in March and applied 2,000 ppm IBA, was the highest $(4.48 \mathrm{~cm})$, and the diameter of the saplings taken in July with one leaf and not applied IBA, was the lowest $(1.55 \mathrm{~cm}$ ) (Table 2). In addition, as the time of obtaining cutting, it has been demonstrated that there is a significant decrease in the diameter of the saplings as we go from winter to summer (Table 2). This may be due to thicker winter cuttings and thinner summer cuttings [17, 26]. In terms of sapling diameter, 500 ppm IBA application stands out. The length of the saplings in leafy cuttings, which were taken in July and applied 2,000 ppm IBA, was the highest with $83.15 \mathrm{~cm}$. In terms of time to collect cutting, it is observed that there is a general increase in the length of the saplings as we go towards the summer months than winter time of cutting collection. In addition, it was determined that the saplings with 2,000 ppm IBA were the highest shoot length with $73.81 \mathrm{~cm}$, while the saplings obtained from cuttings has no IBA were shortest $(55.54 \mathrm{~cm})$. It has been demonstrated that as the applied IBA dose increases, the seedlings grow longer shoots. In terms of salable sapling, May cuttings with 1,000 ppm IBA gave the highest value with 89.33\% (Table 2). July cuttings (84.00\%) and 1,000 ppm IBA dose (77.33\%) resulted in the highest salable sapling rate. Auxin (IBA) application generally increased the rate of salable saplings (Figures 3 and 4). Similar results were reported by Çelik (2012). It is known that, the diameter of the cuttings can affect the growth and development of saplings [17]. On the other hand, it is stated by Graca [33] that the amount of light affects the quality of the saplingduring both rooting and growing period.

Table 2. Sapling diameter, length and salable sapling rate of Autumn olive berry cuttings taken at different time and treated with different IBA doses

\begin{tabular}{ccccc}
\hline Cutting time & IBA $(\mathrm{ppm})$ & Sapling diameter $(\mathrm{cm})$ & Sapling Length $(\mathrm{cm})$ & Salable Sapling Rate (\%) \\
\hline March & 0 & 4.47 & 55.70 & 46.67 \\
& 500 & 4.26 & 62.55 & 45.33 \\
& 1,000 & 4.35 & 53.65 & 56.00 \\
May & 2,000 & 4.48 & 66.18 & 45.33 \\
& 0 & 2.50 & 56.22 & 73.33 \\
& 500 & 2.60 & 62.92 & 85.33 \\
& 1,000 & 2.41 & 64.77 & 89.33 \\
July & 2,000 & 2.18 & 72.10 & 80.00 \\
& 0 & 1.55 & 54.70 & 86.67 \\
& 500 & 1.76 & 59.37 & 88.00 \\
& 1,000 & 1.68 & 76.52 & 86.67 \\
\hline
\end{tabular}

*NS: non significant 
According to Pearson's correlation values, there is positive relation between rooting rate and root length and rooting degree and seedling length. However, it has been determined that there are negative relations between seedling diameter, rooting rate and root length. On the other hand, while there is a positive relationship between the number of roots and the diameter of the saplings and the length of the seedlings and the degree of rooting, root length and rooting rate, other relationships were found to be negative. As the length of the saplings increased, the diameter of the seedlings decreased, and the diameter of the seedlings decreased as the rooting rate increased (Table 3). Because of the growth and development of saplings, the diameter of the shoots can also be affected [17].

Table 3. Pearson correlation between rooting, root quality and sapling characteristics of vegetative propagated Autumn olive berry

\begin{tabular}{cccccc}
\hline & Rooting rate (\%) & Root length $(\mathrm{cm})$ & Root number & Rooting degree (1-9) & Sapling diameter $(\mathrm{cm})$ \\
\hline Root length $(\mathrm{cm})$ & $0.769^{* *}$ & & & & \\
Root number & $-0.859^{* * *}$ & $-0.742^{* *}$ & & & \\
Rooting degree & $0.723^{* *}$ & $0.638^{* *}$ & $-0.518^{* *}$ & & \\
Sapling diameter $(\mathrm{cm})$ & $-0.862^{* * *}$ & $-0.844^{* *}$ & $0.744^{* *}$ & $-0.693^{* *}$ & \\
Sapling length $(\mathrm{cm})$ & 0.245 & 0.188 & -0.241 & $0.402^{*}$ & -0.232 \\
\hline
\end{tabular}

Significancy: ${ }^{*} \mathrm{p}<0.05,{ }^{* *} \mathrm{p}<0.01$

\section{Conclusion}

Autumn olive berry, which is an alternative and newly introduce berry fruit for Turkey, is a very good ornamental plant as well as fence, trenches, wind break and erosion prevention plant. In addition, it has a great importance in the afforestation of the barren areas and the rehabilitation of the mine areas with its soil protective and nutritious feature. Due to its high lycopene content, it is useful for human diet as functional foods and able to withstand the cardiovascular diseases and some certain types of cancer prevention. In this experiment, the best result in terms of rooting was obtained in cuttings collected in July and applied 1,000 ppm auxin (IBA) (97.33\%), followed by May cuttings. This means that leafy cuttings taken from current season active growing shoots are most useful for autumn olive berry propagation than dormant cuttings. However, the rate of salable saplings was highest in May and 1,000 ppm IBA application (89.30\%). And, 1,000 ppm IBA dose and May as cutting time gave the highest values in terms of almost all criteria. Leaf number of the herbaceous cuttings, shade rate during rooting and humidity and misting conditions must be studied with registered cultivars.

\section{References}

[1] Ahmad, S. D., Sabır, M. S., Juma, M., and Asad, H. S. (2005). Morphological and biochemical variations in Elaeagnus umbellata Thunb. From mountains of Pakistan. Acta Botanica Croatia, 64, 121-128.

[2] Ahmad, S. D., Sabır, M. S., and Zubair, M. (2006). Ecotype diversity in autumn olive (Elaeagnus umbellata Thunb.): A single plant with multiple macronutrient genes. Chemistry and Ecology, 22, 509-521.

[3] Çelik, H., Ateş, S., and Çelik, D. (2014). Güzyemişi, yeni alternatif meyve. Hasad, Aylık Bitkisel Üretim Dergisi, 30, 56-60.

[4] Black, B. L., Fordham, I. M., Perkins-Veazie, P. (2005). Autumn berry (Elaeagnus umbellata): a potential cash crop. Journal of the American Pomological Society, 59, 125-134.

[5] Allan, P. F. and Steiner, W. W. (1972). Autumn olive for wildlife and other conservation uses. Leaflet No. 458. Washington, DC: U.S. Department of Agriculture. Pp. 1-8.

[6] Tiffney, W., Eveleigh, D., Barrera, J., and Mitchell, S. (1979). Evaluation of some nitrogen-fixing plants for coastal zone management applications. Symbiotic nitrogen fixation in the management of temperate forests. Oregon State University, USA.

[7] Smith, C. L. (1998). Exotic Plant Guidelines. North Caroline State Univ., NC Division of Parks and Recreation, USA.

[8] Reich, L. (2005). Uncommon Fruits for Every Garden. Timber Press, USA.

[9] Clark, J. and Hemery, G. (2006). The use of autumn olive (Elaeagnus umbellata Thunb.) in British forestry. Quarterly Journal of Forestry, 100, 285-288.

[10] Anonymous. (2012). Invasive Species, best control practices, autumn olive. Michigan Natural Features Inventory 2, p. 7.

[11] Çelik, H., Karabulut, B., Söyler, B., Çelik, D., Demirel, G., and Işık, Y. (2012). Güzyemişi (Eleagnus Umbellata Thunb.)'nin bazı pomolojik özellikleri ile tohumlarının çimlenmesi üzerine dışsal giberellin uygulaması ve soğukta katlamanın etkileri. $I V$. Ulusal Üzümsü Meyveler Sempozyumu, Antalya, Türkiye, 3-5 Ekim 2012, 314-323.

[12] Soley, N. (2013). Reproductive biology of the invasive plant Elaeagnus umbellata: breeding system, pollinators and implica- 
tions for invasive spread. MSc Dissertation, Southern Illinois Univ., USA.

[13] Funk, D. T., Schlesinger, R. C., and Ponder, F. (1979). Autumn olive as a nurse plant for black walnut. Botanical Gazette, 140, 110-114.

[14] Stark, C. (2000). Control of Elaeagnus umbellata-(Autumn olive). Restoration and Reclamation Review, 6, 1-6.

[15] Fordham, I. M., Zimmerman, Z. H., Black, B. L., Clevidence, B. M., and Wiley, E. R. (2003). Autumn olive: A potential alternative crop. Acta Horticulturae, 626, 437-439. http://dx.doi.org/10.21273/HORTSCI.36.6.1136.

[16] Çelik, H. (2012). Yüksek boylu maviyemiş çeşitlerinde köklenme üzerine çelik tipi, çelik alma zamanı ve köklenme ortamının etkisi. IV. Ulusal Üzümsü Meyveler Sempozyumu, Antalya, Türkiye, 3-5 Ekim 2012, 324-335.

[17] Hartmann, H. T., Kester, D. E., and Davies, F. T. (1990). Plant Propagation Principles and Practices, $5^{\text {th }}$ Ed. Englewood Cliffs New Jersey, USA.

[18] Çelik, H. (2006). Kuzey orijinli yüksek çalı maviyemiş yumuşak odun çeliklerinde köklenme üzerine alttan 1sıtma sıcaklığının etkisi. II. Ulusal Üzümsü Meyveler Sempozyumu, Tokat, Türkiye, 14-16 Eylül 2016, 129-135.

[19] Çelik, H., İslam, A., and Kalkışım, Ö. (2015). Effect of cutting time and IBA application on rooting of edible cherry laurel (Prunus laurocerasus cv. 'Kiraz') cuttings. Anadolu Journal of Agricultural Sciences, 30, $215-220$. http://dx.doi.org/10.7161/anajas.2015.30.3.215-220.

[20] Baktır, I. (2015). Hormonlar, Bitki Gelişim Düzenleyicileri Özellikleri ve Tarımda Kullanımları. Hasad Yay. Turkey.

[21] Porghorban, M., Moghadam, E. G., and Asgharzadeh, A. (2014). Effect of media and indole butyric acid (IBA) concentrations on rooting of Russian olive (Elaeagnus angustifolia L) semi-hardwood cuttings. Indian Journal of Fundamental and Applied Life Sciences, 4, 517-523.

[22] Bayraktar, A., Yildırım, N., Atar, F., and Turna, İ. (2018). Effects of some auxins on propagation by hardwood cutting of Autumn Olive (Elaeagnus umbellataThunb.). Turkish Journal of Forestry Research, 5, 112-116. http://dx.doi.org/10.17568/ogmoad.401438.

[23] Bounous, G., Bullano, F., and Peano, C. (1992). Propagation of softwood cuttings of Amelanchiercanadensis Medic., Cornus mas L., Elaeagnus umbellata Thunb. and Hippophea rhamnoides L. Turin Univ. Istituto di Coltivazioni Arboree. Monti-e-Boschi, 43, 51-57.

[24] Beyl, C. A., Burger, D. W., and Cheng, Z. M. (2015). Plant Growth Substances Used in Propagation. Plant Propagation Concepts and Laboratory Exercises. CRC Press, USA.

[25] Osburn, L. D., Chenng, Z. M., and Trigiano, R. N. (2015). Adventitious Rooting of Woody and Hebaceous Plants. Plant Propagation Concepts and Laboratory Exercises. CRC Press, USA.

[26] Ruter, J. M. (2015). Cloning Plants by Stem Cuttings. Plant Propagation Concepts and Laboratory Exercises. CRC Press, USA.

[27] Preet, P. and Vishal, S. R. (2014). Studies on the effect of some pre-conditioning treatments, IBA and collection time on the success of semi-hardwood cuttings on kiwifruit. Indian Journal of Horticulture, 71, 273-276.

[28] Zenginbal, H. and Özcan, M. (2013). Hayward ve Matua kivi çeşitlerinin odun çelikleriyle çoğaltılmasında farklı uygulamaların etkileri. Anadolu Tarm Bilimleri Dergisi, 28, 115-125. http://dx.doi.org/10.7161/anajas.2013.28.3.115.

[29] Zenginbal, H. and Özcan, M. (2014). Kivide çelik alma zamanı çelikteki göz sayısı ve IBA uygulamalarının çeliklerin köklenmesi üzerine etkileri. Anadolu Tartm Bilimleri Dergisi, 29, 1-11. http://dx.doi.org/10.7161/anajas.2014.29.1.1.

[30] Kim, M. S., Kim, H., and Kim, S. H. (2015). Effect of cutting time and growth regulators in root cutting of Robinia pseudoacacia L. major honey plants. Journal of Apiculture, 30, 331-336.

[31] Şeker, M., Akçal, A., Sakaldaş, M., and Gündoğdu, M. A. (2010). Farklı çelik alma dönemleri ile oksin dozlarının kocayemişin (Arbutus unedo L.) köklenme oranı üzerine etkilerinin belirlenmesi. Uludă̆ Universitesi Ziraat Fakültesi Dergisi, 24, 99-108.

[32] Pivetta, L., Fernandes, K., Renet, D. P., and Silvio, F. (2012). Harvesting time and indolebutryic acid on the rooting of Nerium oleander L. Cuttings. Rivista Arvore, 36, 17-23. http://dx.doi.org/10.1590/S0100-67622012000100003.

[33] Graca, M. E. C. (1983). Influence of light intensity on growth, nodulation and nitrogen fixation of selected woody actinorhizal species. PhD Dissertation, Purdue Univ. USA. 